\title{
The Continuity of Icelandic Names and Naming Patterns
}

\author{
RICHARD F. TOMASSON
}

NLY IN ICELAND has the centuries old Scandinavian pattern of naming continued down to the present. One's given name is one's primary name. One is listed in the telephone book, in library card catalogs (except in the National Library), and in directories and files as Jón or Guðrún. One's second name is a patronymic formed by adding son or dóttir to the possessive of one's father's name, and women do not change their names after marriage. Everywhere else in Scandinavia family names became legally necessary in the nineteenth or carly twentieth centuries.

In 1913 legislation was passed in Iceland requiring the petitioning of the government to adopt a family name and it was required that the name be of a suitable type. ${ }^{1}$ This legislation further required the drawing-up of official lists of acceptable Icelandic family names and given names. The reason for this legislation was to stem the tide in the adoption of family names and in the use of given names of foreign origin. Such practices had begun in the seventeenth and eighteenth centuries and rapidly increased during the nineteenth among Danophilic Icelanders. In 1855 there were 108 different family names in Iceland; by 1910 the number had increased to $297 . .^{2}$ In 1925 additional name legislation was passed prohibiting the adoption of family names altogether, though allowing those who already had them to keep them; it also made the adoption of an Icelandic patronymic a prerequisite for obtaining Icelandic citizenship. A check of the 1972 Icelandic telephone directory indicates about 15 percent of Icelanders continue to have family names. ${ }^{3}$

The continuity of names throughout Icelandic history has been striking as a perusal of Tables 1 and 2 demonstrates. These tables

\footnotetext{
1 Einar Hjörleifsson, et. al., Íslenzk mannanöfn: lög, nefndarálit og nafnaskrár (Reykjavík: Gutenberg, 1915).

2 porsteinn porsteinsson, Íslenzk mannanöfn samkvæmt manntalinu 1 des. 1910 (Reykjavík: Hagskýrslur íslands 5, 1915), p. 14.

3 This is also the conventional estimate of the proportion of Icelanders with family names. This percentage may be declining; I have heard of some Icelanders who are dropping family names and reverting to the conventional Icelandic naming pattern.
} 
give the rank order frequency of male and female names for six periods in the 1,100 years of Icelandic history; all names are spelled with modern orthography. They are based on name counts of about 6,800 persons from Saga Times (AD 870-1030), about 4,000 persons from the twelfth and thirteenth centuries (Age of the Sturlungs), complete counts of names enumerated in the censuses of 1703, 1855, and 1910, together with a frequency count of all children born in Iceland in the years 1921 through 1950 which I take as an approximation of the rank order frequency of names for the years around 1970. (The sources from which these frequencies were calculated are given in Table 1.) Study of these name frequencies indicates that a large majority of Icelanders have the same names as their ancestors of seven and eight centuries ago. More remarkable, however, is the observation that most of the names of the men and women who settled Iceland in the years 870-930 are to be found in contemporary Iceland. Of the 27 most common male names from Saga Times (almost 5,000 of the 6,800 known persons are male) all are at least fairly common in Iceland today. ${ }^{4}$ The same is true with one exception (Álöf) of the 27 leading female names (about 2,000 of the known persons from Saga Times are female). There were no Álöfs born in 1921-50; nor are there any listed in the 1972 Icelandic telephone directory. However, the very similar name Olöf remains a leading name in contemporary Iceland as it was in Saga Times. No such continuity as this characterizes the Anglo-Saxon names in use a millennium ago; most sound ancient and distant to our ears. ${ }^{5}$

In spite of the continuity in names over the 11 centuries of Icelandic history, a number of trends may be noted:

(1) There has been a marked decline in pór names. In preChristian times about 25 percent of all names commemorated this most vigorous and vital of the Viking gods. During the twelfth and thirteenth centuries, after Christianity had been established for several generations, por names had declined to about 14 percent of all names. In the census enumerations of 1703, 1855, and 1910, eight or nine percent of all names were fór names; there was no decline over these two centuries. Around 1970, however, only about four percent of all names were pór names. In the overwhelming

\footnotetext{
4 In fact most of these leading names from Saga Times can be said to be leading names in contemporary Iceland. See the frequencies in porsteinn porsteinsson, Islenzk mannanöfn, 1921-1950 (Reykjavík: Bókaútgáfa menningarsjóðs, 1961).

5 Note the names in the index to some history of early England such as Dorothy Whitelock, The Beginnings of English Society (Baltimore: Penguin Books, 1952), pp. 249-256.
} 
Table 1. Rank Order of Frequency of Male Names from Saga Times to the Present

(Names for 1703 through 1970 include all names accounting for at least one percent of names.)

\begin{tabular}{|c|c|c|c|c|c|c|}
\hline Rank & Saga Times & 12-13 Cent. & 1703 & 1855 & 1910 & Ca. 1970 \\
\hline 1 & porsteinn & pórður & Jón & Jón & Jón & Jón \\
\hline 2 & pórour & Jón & Guðmundur & Guðmundur & Guðmundur & Guðmundur \\
\hline 3 & porkell & porsteinn & Bjarni & Sigurður & Sigurður & Sigurður \\
\hline 4 & bórir & Einar & Sigurður & Magnús & Ólafur & Gunnar \\
\hline 5 & Björn & Guðmundur & Ólafur & Ólafur & Magnús & ólafur \\
\hline 6 & Grímur & Eyjólfur & Magnús & Einar & Kristján & Magnús \\
\hline 7 & porbjörn & Snorri & Einar & Bjarni & Einar & Kristján \\
\hline 8 & Helgi & Björn & porsteinn & Árni & Bjarni & Einar \\
\hline 9 & porgeir & Ólafur & pórður & Gísli & Jóhann & Jóhann \\
\hline 10 & pórarinn & Brandur & Árni & Björn & Björn & Kristinn \\
\hline 11 & porgrímur & porkell & Gísli & Kristján & Gísli & Helgi \\
\hline 12 & Sigurður & Halldór & Björn & porsteinn & Árni & Björn \\
\hline 13 & porvaldur & Sigurður & Halldór & Stefán & Stefán & Halldór \\
\hline 14 & Ketill & Magnús & Eiríkur & Jóhannes & porsteinn & Stefán \\
\hline 15 & Einar & Hallur & Páll & Jóhann & Helgi & Bjarni \\
\hline 16 & porgils & Árni & Sveinn & Jónas & Guđjón & pór \\
\hline 17 & Bárđur & pórarinn & Oddur & pórður & Halldór & Ragnar \\
\hline 18 & Eyjólfur & porgeir & Pétur & Sveinn & Kristinn & Árni \\
\hline 19 & pormóður & Páll & Eyjólfur & Halldór & Páll & Pétur \\
\hline 20 & Eyvindur & porgils & Helgi & Páll & Jóhannes & Gísli \\
\hline 21 & porleifur & Oddur & Tómas & Pétur & Pétur & Páll \\
\hline 22 & pórólfur & Grímur & porleifur & Eiríkur & pórður & Guðjón \\
\hline 23 & Oddur & Ketill & porkell & Helgi & Sveinn & porsteinn \\
\hline 24 & Ormur & Helgi & Snorri & Eyjólfur & Gunnar & Sveinn \\
\hline 25 & Hrafn & Bárður & Sigmundur & Benedikt & Jónas & Karl \\
\hline 26 & Olafur & porbjörn & & & Ágúst & Örn \\
\hline 27 & porfinnur & pórir & & & Sigurjón & Jóhannes \\
\hline 28 & & porvaldur & & & & Haukur \\
\hline 29 & & & & & & Oskar \\
\hline 30 & & & & & & Ágúst \\
\hline & & & & & & Ingi \\
\hline & & & & & & Birgir \\
\hline & & & & & & Sigurjón \\
\hline
\end{tabular}

Sources:

Rank order of frequency of names in Saga Times was calculated from Guðni Jónsson, Islendinga sögur: nafnaskrá (Reykjavík: Íslendingasagnaútgáfan, 1968) and is based on about 6,800 names. Twelfth and thirteenth centuries data from about 4,000 names in index to Jón Jóhannesson, Magnús Finnbogason, and Kristján Eldjárn, Sturlunga Saga (Reykjavík: Sturlunguútgáfan, 1946), Vol. II, pp. 363-473. Data for 1703 are from the census of that year: Ólafur Lárusson, Nöfn islendinga árið 1703 (Reykjavík: Hið íslenzka bókmenntafélag, 1960). Data for 1855 are from the census of that year: Sigurð Hansen, "Um mannaheiti á Íslandi, arið 1855," Skýrslur um landshagi á Islandi (Copenhagen: Hinu íslenzka bókmenntafélagi, 1858), Vol. I, pp. 503-572. Data for 1910 are also from the census of that year: porsteinn porsteinsson, Islenzk mannanöfn 
samkvæmt manntalinu 1 des. 1910 (Reykjavík: Hagskýrslur Íslands 5, 1915). The rank order of names for circa 1970 is based on a frequency count of the names of all children born in Iceland 1921-1950: porsteinn porsteinsson, Islenzk mannanöfn: nafngiafir Priggia áratuga 1921-1950 (Reykjavík: Bókaútgáfa menningarsjóðs, 1961), p. 13.

Table 2. Rank Order of Frequency of Female Names from Saga Times to the Present

(Names for 1703 through 1970 include all names accounting for at least one percent of names.)

\begin{tabular}{|c|c|c|c|c|c|c|}
\hline Rank & Saga Times & 12-13 Cent. & 1703 & 1855 & 1910 & Ca. 1970 \\
\hline 1 & porgerður & Gưrún & Guđrún & Gưrún & Guđrún & Guðrún \\
\hline 2 & pórdís & Helga & Sigríđur & Sigríđur & Sigríđur & Sigríður \\
\hline 3 & puríður & pórdís & Ingibjörgr & Margrét & Kristín & Kristín \\
\hline 4 & Helga & Valgertur & Margrét & Kristín & Margrét & Margrét \\
\hline 5 & Guðrún & puríður & Helga & Ingibjörg & Ingibjörg & Ingibjörg \\
\hline 6 & póra & Halldóra & puriotur & Helga & Anna & Anna \\
\hline 7 & pórunn & Sigríður & Kristín & Anna & Helga & Helga \\
\hline 8 & Sigrítur & Steinunn & Valgerour & Guðbjörg & Jóhanna & Jóhanna \\
\hline 9 & porbjörg & Hallbera & Halldóra & Gưný & Guđbjörg & Sigrún \\
\hline 10 & Valgerđur & Herdís & Ólöf & Jóhanna & Jónína & María \\
\hline 11 & Rannveig & porgerour & Guðný & Guðríður & María & Jóna \\
\hline 12 & Vigdís & Ingibjörg & Guđríður & Halldóra & Guðný & Guðbjörg \\
\hline 13 & porkatla & póra & Steinunn & Steinunn & Halldóra & Erla \\
\hline 14 & Ingibjörg & Kolfinna & póra & puríður & Gưríður & Hulda \\
\hline 15 & Gróa & Oddný & pórunn & pórụnn & Steinunn & Guđný \\
\hline 16 & Jórunn & Álöf & porbjörg & Ólöf & Elín & Elín \\
\hline 17 & Halldóra & Guðný & Ragnhildur & Valgerður & pórunn & Ragnheiður \\
\hline 18 & Hildur & Hallfriour & Ingveldur & Elín & Guðlaug & Steinunn \\
\hline 19 & Hallbera & Vigdís & bórdís & porbjörg & Olöf & ólöf \\
\hline 20 & Álöf & porbjörg & Sesselja & Guðlaug & Sigurbjörg & Björg \\
\hline 21 & pórhildur & Halla & Katrín & Sólveig & Valgerður & Jónína \\
\hline 22 & Ragnhildur & Margrét & Guðlaug & María & puríđur & Ásta \\
\hline 23 & Ástríđur & Álfheiður & Sólveig & Hólmfríđur & Hólmfríđur & Halldóra \\
\hline 24 & Auður & Birna & Gróa & Björg & Ragnheiður & póra \\
\hline 2.5 & Guðríður & Jórumn & porgerđur & Ragnheiður & porbjörg & Sigurbjörgr \\
\hline 26 & Gunnhildur & & Vigdís & Ragnhildur & Kristjana & Lilja \\
\hline 27 & Ólöf & & Oddný & Sesselja & Elísabet & bórunn \\
\hline 28 & & & Vilborg & & bóra & Guðlaug \\
\hline 29 & & & Anna & & Björg & Unnur \\
\hline \multirow[t]{3}{*}{30} & & & & & Sólveig & Sólveig \\
\hline & & & & & & Elísabet \\
\hline & & & & & & $\begin{array}{l}\text { Valgerður } \\
\text { Erna }\end{array}$ \\
\hline
\end{tabular}

Sources: See Table 1 . 
majority of cases bór is the first part of a compound name, but in a minority of cases it is the end part as in Bergpór or Bergpóra, Steinpór or Steinpóra. Sometimes, the $p$ becomes $d$ as in Halldór and Halldóra. In one case there is a consonant change: the leading female name puridur (from the male porriður) must be reckoned a pór name."

(2) From the beginning there has been a continual increase in biblical and Christian names. A very small number of the 3,500 original settlers listed in Landnámabók (The Book of Settlements) had biblical names like Jón, Pétur, Páll, and Margrét. ${ }^{7}$ Still, however, the great majority of Icelanders down to the present have borne Old Norse names.

(3) Until the eighteenth century virtually no Icelanders had more than one name while among those born in the years 1941195052 percent had two or more given names. ${ }^{8}$ In the 1703 census only two individuals in the whole country, a brother and sister, were enumerated as having two given names. ${ }^{9}$

(4) From the beginning Icelanders have continually made up new names by compounding names, but the process greatly accelerated in the nineteenth century when many new combinations came into existence like Friðjón and Bergjón.

(5) From the nineteenth century there has been an increasing tendency to use foreign names, a few of which have become very common (e.g., Kristinn and Hulda), a distressing trend to some Icelanders. Most of the leading foreign names have come to Iceland via Denmark.

Throughout Icelandic history relatively few names have been used by the majority of the population. In the 1703 census 387 male and 3.38 female names were counted. ${ }^{10}$ However, 23.5 percent of the males were named Jón, probably the most common male name at all times from the thirteenth century. The ten most frequent male names in this early census were held by over half the males. Among females, the most common name in 1703, as it has been since at least the twelfth century, was Guðrún; this was the given

${ }^{6}$ Noted by Assar Janzén, "De fornvästnordiska personnamen," in Personnavne: Nordisk Kultur VII (Stockholm: Albert Bonniers förlag, 1947), pp. 22-186, p. 95.

7 Ibid., p. 29. See also Jakob Benediktsson, "Landnámabók: Some remarks on its value as a historical source," Saga-Book of the Viking Society for Northern Research, Vol. XVII (Part 4, 1969), pp. 275-292; and the Nafnaskrá to Landnámabók (Reykjavík: Hið íslenzka fornritafélag, 1968), Vol. II, pp. 441-525.

8 Islenzk mannanöfn, 1921-1950, p. 11.

9) Ólafur Lárusson, Nöfn íslendinga árið 1703 (Reykjavík: Hið islenzka bókmenntafélag, 1960), p. 3.

10 Ibid., p. 3. 
name of 19.7 percent of all females. As with males the ten most common names accounted for a majority of all females enumerated.

Among Icelanders born in the years 1921-1950 the number of recorded names more than tripled to 1,234 for males and 1,463 for females. ${ }^{11}$ Yet, however, between a third and a half of both males and females had the ten most frequent names. Sixty-four percent of the male names were held by fewer than 50 individuals and 31 percent were held by only one person. Among female names 73 percent were counted fewer than 50 times and 30 percent only once. The use of Jón declined to 6.5 percent of all males, Guðrún to 7.8 percent of all females.

The leading male names have close to the same rank order of frequency at present as in 1703 and perhaps for several centuries before that. The most notable exception is Gunnar which moved from thirty-fifth place in 1703, to thirty-third place in 1855, to twenty-fourth place in 1910, and to fourth place in the present era. Significantly this is the name of the greatest of all heroes in the Sagas of the Icelanders, Gunnar of Hlidarend in Njáls saga. The name Bjarni, on the other hand, declined from third place in 1703 to seventh place in 1855 to eighth place in 1910, and to fifteenth place among males born in 1921-1950. Of the 33 most common male names listed in Table 1 for the most recent period at least 24 go back to the Age of Settlement (870-930). ${ }^{12}$ Kristián and Kristinn are Danish imports and were rarely used in Iceland prior to the eighteenth century. Jóhann and Jóhannes, variations of the biblical name Jón, came into Iceland in the seventeenth century or earlier; there were only 11 Jóhanns and one Jóhannes enumerated in 1703. Stefán dates from the thirteenth century. Guðjón is a name which was unknown in 1703, but became common in the nineteenth century; it is a typical Icelandic compound and is simply Icelandic for God's Jón. Oskar and Ágúst date from the eighteenth or early nineteenth centuries. Sigurión, in thirtythird place, is another nineteenth century compound, but, unlike Guðjón, has no meaning.

There is clearly less continuity with female than with male names. Of the 33 most common female names for the present period listed in Table 2 not fewer than 18 go back to the Age of Settlement. Kristin, the third most common name among females born in the 1921-1950 period, is a Christian name which was

11 Islenzk mannanöfn, 1921-1950, p. 12.

12 Much of the specific information on Icelandic names in this and the subsequent paragraph is from Hermann Pálsson, Íslenzk mannanöfn (Reykjavík: Heimskringla, 1960 ); see also Assar Janzén, op. cit. 
introduced into Iceland in the thirteenth century, since which time it has always been one of the most common names in Iceland. Anna was introduced into Iceland in the fifteenth century and is the sixth most common female name among those born in the years 1921-1950; it was twenty-ninth in frequency among those enumerated in 1703, but jumped to eighth place in 1855 , and to sixth place in 1910 where it has remained. Jóhanna, a feminine form of Jóhann, is of Danish origin and goes back to the seventeenth century. Sigrún was not used in Iceland before the fifteenth century although the name is found in The Saga of the Volsungs written in the thirteenth century. Maria, another Christian name, did not come into use until the eighteenth century; there were no Marias enumerated in 1703. ${ }^{13}$ Jóna, the feminine of Jón, became popular in the late nineteenth century; only one Jóna was enumerated in 1703. Erla is of very recent vintage in Iceland; none was enumerated as recently as 1910. Hulda is a late nineteenth-century import from Denmark. Elin is of non-Norse origin (from Greek Helena) and was not used in Iceland before the fifteenth century. Jónina, a feminine diminutive of Jón, is probably a nineteenthcentury invention. Ásta is a shortening of the ancient Norwegian name Ástríði, and was not used in Iceland before the thirteenth century. Six Sigurbjörgs were counted in 1703, a compound name of old Norse roots probably invented in the seventeenth century. Lilia was not used in Iceland prior to the eighteenth century. Elisabet dates from the seventeenth century. ${ }^{14}$ The name Erna is from the mythological literature of ancient Iceland (Rigspula); only three were enumerated in 1910.

Some of the wives and slaves who accompanied the original Norse settlers were Irish. They are responsible for a small number of Irish words in the Icelandic language. including a few proper names. The most common have been the male names Kjartan (Certán), Kormákur (Cormac), and Njáll (Níall), together with the female name Melkorka (Mael Curcaig). All of these are the names of well-known Saga characters, yet not since the earliest generations have more than a fraction of one percent of Icelanders borne Irish names. By far the most common has been Kjarten, also the name of an enormously illustrious and handsome figure in Laxdaela Saga, but of the males born in 1921-1950 only 261

13 There were, however, four women in 1703 with the male-sounding name Mario. See Nöfn islendinga árið 1703, p. 38.

14 However, a northern version of this name was Ellisif and was used in Iceland from the thirteenth through the eighteenth century. See Hermann Pálsson, op. cit., p. 186. 
had this as a single, first, or auxiliary name; only 15 were enumerated in 1703 .

Several patterns in the naming of children have persisted since Saga Times and earlier. ${ }^{15}$ Sometimes sons have been named after their fathers, but this has never been a common pattern either among the Old Norse nor among contemporary Icelanders. Of about 1,100 Jóns listed in the Reykjavík section of the 1972 Icelandic telephone directory, only 21 have the patronymic Jónnson. Rarely, at any time, have daughters been named after their mothers. Three naming patterns have been common from the beginning: alliteration, variation, and commemoration. A stunning example of the alliterative pattern is the successive list of kings of the Uppsala dynasty who have been named Agni, Alrek, Ygnvi, Iorund, Aun, Egil, Ottar, Adils, Eystein, Yngvar, Qnund, Ingiald, and Olaf. ${ }^{16}$ That this was a pervasive Old Germanic pattern is suggested by the names of Alfred the Great's children: Ethelflaed, Edward, Edmund, Ethelgifu, Aelfthryth, and Ethelweard. ${ }^{17}$ Some contemporary Icelandic couples continue to have children with alliterative name combinations such as Gunnar, Gunnilla, and Guðbjörg. Probably always more common, however, has been the variation principle, and this pattern is probably older than the alliteration pattern having arisen before the Germanic languages were separated from the main stock; it appears in Greek. ${ }^{18}$ Here names with similar beginnings or endings are used to show family relationships. In Iceland and Ancient Scandinavia variations of the first element rather than the end element have been much more common. ${ }^{19}$ In Landnámabók there is an account of a settler from Sogn in Norway named Végeir (which means Temple-Geir or Holy-Geir); he had six sons named Vébjörn, Vésteinn, Vépormur, Vémundur, Végestur, and Véporn, plus a daughter named Védís. The helpful brothers in Hrafnkel's Saga were named porgeir and porbjörn, and they have a third brother named pormóður. Such a combination would not be unusual

15 For Old Norse patterns of naming, see Assar Janzén, op. cit.; also, see articles on "Namngjeving" and "Personnavn" in Kulturhistorisk Leksikon for nordisk middelalder (Reykjavík: Bókaverzlun Ísafolder, various years).

16 Noted in Peter Foote and David M. Wilson, The Viking Achievement (London: Sidgwick \& Jackson, 1970), p. 115.

17 Eleanor Shipley Duckett, Alfred the Great (Chicago: University of Chicago Press, 1956); see family tree opposite p. 1.

18 E. G. Withycombe, The Oxford Dictionary of English Christian Names (Oxford: Clarendon Press, 1950, Second Edition), pp. xxiii-xxiv.

19 For a discussion of these elements in Icelandic names, see Roland Otterbjörk, "Moderna islïndska förnamn," Scripta Islandica (Sweden), Årsbok 14 (1963), pp. 27-41. 
in contemporary Iceland. Once again it is appropriate to note Alfred the Great whose father was named Ethelwulf and whose brothers were Ethelbald, Ethelbert, Ethelred, and Ethelswith.

Far more common, however, than either of these patterns has been commemoration, particularly the naming of a son after an ancestor, above all a paternal grandfather. Ari porgilsson (10671148), the father of Icelandic history, had a son named porgils Arason, who, in turn, had a son named Ari porgilsson. It has always been common in Iceland, and perhaps more so now than ever in the past, to have name reversals such as this. A sizeable proportion of contemporary Icelandic males have the same names as their paternal grandfathers.

University of New Mexico

\section{JAPANESE ONOMATOLOGIST DIES}

Dr. Ei Sakuma, former lecturer at the Japan Dental College and authority on Japanese family names, died on December 16, 1975, at the age of 62. Some of his works are Onamae haiken (Show me your Name), Chinsei kimei (Curious Names), Nihonjin-no sei (Japanese Family Names) and Onamae fudoki (Topography on Family Names). Although not a member of the American Name Society, he was widely known in the scholarly world both in this country and abroad. 